\title{
Sobre dedos secos se tiende un lienzo. Algunas pinceladas reflexivas sobre la obra de Yina Raquel Lopera*
}

\section{Hilderman Cardona-Rodas}

Universidad de Medellín, Medellín, Colombia hcadona@udem.edu.co

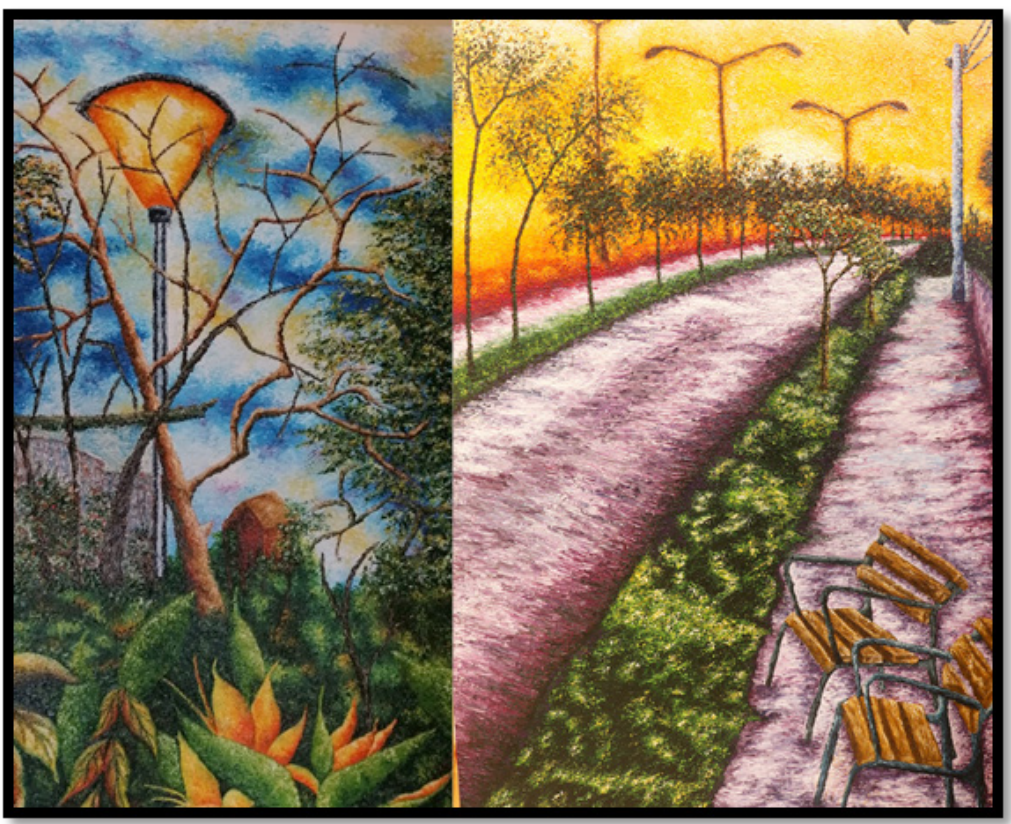

Obras Contemplación y Memorias de Yina Raquél Lopera

John Ruskin (1819-1900) dijo alguna vez que "la belleza del fruto está en proporción del tiempo que transcurre entre la semilla y la recolección". Esta frase tiene su reverberación en la serie de obras que la artista Yina Raquel Lopera nos ha permitido utilizar para el número 15 de la revista Ciencias Sociales y Educación. El follaje urbano tiene tu eficacia icónica en sus pinturas: calles, faroles, sillas, vegetación, lugares sagrados y cableados se pliegan en una

Cómo citar: Cardona-Rodas, H. (2019). Sobre dedos secos se tiende un lienzo. Algunas pinceladas reflexivas sobre la obra de Yina Raquel Lopera. Ciencias Sociales y Educación, 8(15), 311-313. DOI: http://10.22395/csye. v8n15a19

Recibido: 15 de mayo de 2019.

Aprobado: 19 de junio de 2019. 
coreografía plástica que proyecta la belleza en el fruto de un trabajo estético pincelado. Las obras que integran la revista, todas realizadas en 2018, presentan una perspectiva corporeal donde el acontecimiento pintado narra el devenir de la experiencia estética en seis piezas: Contemplación; Memoria; Territorios de violencia; Tramas; Otras miradas y Recorridos a partir de la técnica del óleo sobre lienzo. Cada una de ellas integra una serie donde la intensidad del color se hace palpable al proyectar figuras de carne intensa que dejan la sensación de desplegar movimientos semióticos y corporales en el flâneur urbano y rural, además de sus procesos plásticos de creación artística. He aquí esa imagensíntoma que late en el corazón mismo de cada obra.

Somos habitados por dichas imágenes, nos materializamos como cuerpos ligados a fuerzas de enunciación deseantes, por un bloque de sensaciones que se expresa en nuestra contemplación de la belleza, entendida como un territorio de lo terrible palpitante en una dialéctica de resonancias entre alma-cuerpo, o como lo expresó el Pseudo Aristóteles en el siglo III a. C.:

Creo que el alma y el cuerpo están mutuamente vinculados en sus afecciones: si cambia la disposición del alma cambia a su vez la forma del cuerpo; por su parte, asimismo, el cambio en la disposición del cuerpo produce alteraciones en el alma. Ya que la aflicción y la alegría son estados del alma es evidente que los que se encuentran afligidos se muestran muy apesadumbrados, mientras que en quienes sienten alegría se manifiesta gozo. (Pseudo Aristóteles, 2019, p. 47)

Afecciones del alma que se hacen cuerpo en el encuentro estético y en la superficie parlante del acontecimiento que vibra en cada una de las obras de Yina Raquel Lopera. Es apreciable en ellas el cuerpo-vida en tanto universo de las experiencias de lo posible, puesto que cada obra, en una conversión del acto perceptivo en un compuesto de sensación de multiplicidades, encarnan el acontecimiento-obra interpretado como un campo de intensidades y de fuerzas. En la práctica artística, la misma que podría ser pensada para la práctica narrativa del historiador, se ponen en escena niveles de expectación, dimensiones de deseo y posibilidades de sentido desplegadas como discurso, aquello que discurre como lienzo, en los rostros de la afectación estética. El artista, como el historiador, se acerca a los hechos del discurso e interpone una reescritura, una forma mantenida de exterioridad o una transformación de mediación comprensiva de lo que se ve y de lo que se expresa en el lienzo de la escritura. En este sentido el título que encabeza este texto "sobre dedos secos se tiende un lienzo", frase de Paul Klee, traza los campos de materialización de intensidades y fuerzas en las sonoridades del color de la propuesta estética 
de Lopera, la cual reconstruye una posible banda de acontecimientos hechos carne en las imágenes-síntomas de las tempestades que arrancan a la mera imagen las resonancias del compuesto de sensación en cada una de estas seis obras. Paul Klee dice:

Sobre dedos secos se tiende un lienzo.

Luego se quema una salva atronadora.

Después la víctima ya muerta

se presenta en breve a los ojos.

Y luego, tronando los dedos,

se envuelve rápidamente el lienzo.

Solo falta poner título al estremecimiento,

Legendum: una vieja sonándose las narices.

(Klee, 1970, p. 162)

Contemplación; Memoria; Territorios de violencia; Tramas; Otras miradas y Recorridos constituyen ese campo de resonancias discursivas donde una hermenéutica de la mirada hace perceptible esa fábrica de fuegos artificiales, pólvoras multicolores, ramilletes de luz, dedos secos, lienzos acrobáticos de escrituras policromas. Es lo que arriesgamos a decir como un campo de intensidades y fuerzas que posibilitan al sentido como condición emergente plurimolecular en el gesto del óleo sobre lienzo que Yina Raquel Lopera nos ofrece en su mirada-tacto. Y ahora solo queda expresar el título del estremecimiento: el rostro de la afectación creativa. Agradecemos a la artista Lopera haber compartido con la revista su estremecimiento estético.

\section{Referencias}

Klee, P. (1970). Diarios 1898/1918. México: Biblioteca Era.

Pseudo Aristóteles (2019). Fisiognómica. (Trad. Cano, J.). Madrid, España: Márrmara Editores. 